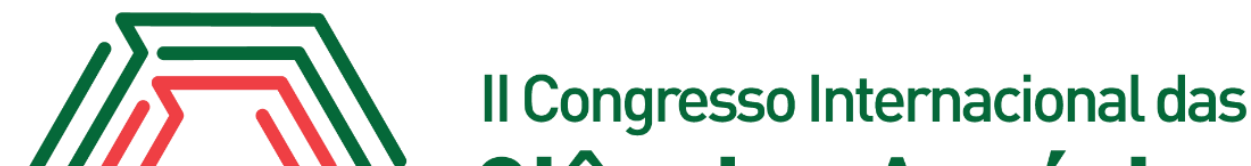 Ciências Agrárias COINTER - PDVAgro 2017
}

\section{DETERMINAÇÃO DA ESTAÇÃO CLIMÁTICA IDEAL PARA COLETAR Sargassum filipendula NO RIO GRANDE DO NORTE}

\author{
Apresentação: Pôster \\ Ilmara Beatriz Menezes Silva ${ }^{1}$; Valéria Nayara Silva de Oliveira ${ }^{2}$; Bárbara Monique de Freitas \\ Vasconcelos $^{3}$; Juliana Rocha Vaez ${ }^{4}$
}

\section{Introdução}

Macroalgas marinhas constituem uma fonte extremamente rica de compostos bioativos, dentre eles, polissacarídeos sulfatados. Sargassum filipendula é um gênero de macroalgas marrons (Ordem: Phaeophycea) que está entre as fontes mais ricas de novos compostos bioativos, como outras algas marinhas. As composições de nutrientes das algas são diferentes dependendo de espécies, habitats, condições ambientais e processos de secagem.

O gênero Sargassum C. Agardh (Sargassaceae) constitui um dos mais representativos dentre os 41 gêneros da ordem Fucales (Phaeophyceae, Heterokontophyta), é amplamente distribuído nas regiões tropicais e subtropicais do globo e é considerado um importante componente da flora marinha (Bjarnsholt, 2013).

Os lipídios são substâncias com grande variedade química, entretanto, exibem uma característica definidora e comum, que é a insolubilidade em água. Nos organismos vivos, as funções dos lipídios são tão diversas quanto à sua composição química. $\mathrm{O}$ armazenamento de energia, na forma de gordura e ácidos graxos, e a composição das membranas celulares, através dos fosfolipídios, são as funções mais proeminentes destes compostos e estão presentes na maioria dos organismos (Azeredo, 2012). O objetivo desse trabalho foi determinar qual a estação climática ideal para se coletar a Sargassum filipendula para se obter maiores níveis de lipídeos para serem usados na obtenção de biodiesel.

\footnotetext{
${ }^{1}$ Agronomia, UFERSA, beatrizmenezesagro@gmail.com

${ }^{2}$ Agronomia, UFERSA, valeria-nayara@hotmail.com

${ }^{3}$ Mestre, UFRN, barbara.biotec1@gmail.com

${ }^{4}$ Doutor, UFERSA, juvaez@ufersa.edu.br
} 


\section{Fundamentação Teórica}

Biocombustível é definido comumente como um combustível derivado de materiais biológicos, incluindo matéria orgânica morta que não esteja fossilizada, e também proveniente de produtos metabólicos de organismo vivos, como, por exemplo, óleo vegetal para a produção de biodiesel (Dermibas, 2009).

Nos últimos anos, visando o aumento no consumo de biodiesel, diversos estudos e pesquisas, incentivadas por ações governamentais, principalmente nos países desenvolvidos, vem sendo realizados com o intuito de, aumentar a produtividade através de modificação genética das culturas existentes, ou encontrar alternativas viáveis para suprir a demanda sem causar maiores impactos sobre o meio ambiente e o abastecimento de alimentos. Como resultado destas pesquisas, está ocorrendo o surgimento de uma nova geração de biocombustíveis, os chamados biocombustíveis de $2^{a}$ geração. O carro chefe destes biocombustíveis é o etanol oriundo da digestão enzimática da celulose. Além dele, os bio-óleos e Syngas (combustível sintético), produzidos a partir da liquefação, ou pirólise da biomassa, vem ganhando atenção no cenário internacional (Azeredo, 2012).

Mais recentemente, uma matéria prima que apresenta enorme potencial e que vem sendo objeto de estudo para fins energéticos, principalmente pelos Estados Unidos, através do Programa de Espécies Aquáticas desde a década de 70, mas que só agora ganhou novo fôlego, são as algas marinhas (Azeredo, 2012).

Existem diversos tipos e sistemas para a produção de biomassa de algas. Esses sistemas podem ser divididos em três tipos: os sistemas autotróficos, que utilizam a luz do sol como principal fonte de energia e $\mathrm{CO}^{2}$ como fonte de carbono para o crescimento das microalgas; os sistemas heterotróficos, que se valem de compostos orgânicos (e.g., glicose, acetato) como principal fonte de energia e carbono para o desenvolvimento da cultura; e, por último, os sistemas mixotróficos que apresentam duas fases, uma autotrófica e outra heterotrófica.

De acordo com Borowitzka (1999), existem diversas considerações a respeito de quais sistemas de cultivo devem ser utilizados. Os fatores a serem avaliados incluem: as características biológicas da espécie de alga a ser usada, os custos da terra, do trabalho e da energia, a disponibilidade e custo daágua e nutrientes, bem como o tipo de produto final. Os diversos sistemas de cultivo em larga escala devem ser comparados em suas propriedades básicas tais como, a sua 
eficiência na utilização da luz, capacidade de controle da temperatura, estresse hidrodinâmico exercido sobre as microalgas e capacidade de manter a cultura estéril, ou seja, sem a presença de outras espécies de microalgas ou predadores (Borowitzka 1999).

\section{Metodologia}

A pesquisa tem caráter, à princípio, quantitativo. As algas foram coletadas no litoral do Rio Grande do Norte na Praia de Rio do Fogo. As coletas foram realizadas nas quatro estações climáticas do ano (verão, outono, inverno e primavera) para que se pudesse haver uma comparação dos dados obtidos. Os teores de proteínas, cinzas, lípidos, carboidrato e umidade de algas foram determinados conforme recomendado pelo Instituto AOAC (2011). Os valores médios de cada componente bioquímico foram submetidos a teste estatístico ANOVA one-way.

\section{Resultados e Discussões}

O tempo de secagem para Sargassum filipendula foi de 150 minutos, neste momento descobrimos que o outono e a primavera apresentaram os melhores resultados para a concentração de lipídios $(5,47 \%$ e $6,77 \%)$. Encontramos o maior nível de proteína no inverno e na primavera $(10,49 \%$ e $13,60 \%)$. Os níveis de cinzas permanecem inalterados nas estações do ano. Obtivemos $60,62 \%$ para o inverno, 53,33\% para a primavera, 64,14\% para o outono, mas a melhor concentração de carboidratos $(72,86 \%)$ foi encontrada no verão. Monitoramos a concentração de compostos biológicos de Sargassum filipendula por dois anos e observamos que a concentração de compostos biológicos desta macroalga é tão não ajustada durante as estações, mas permanece o mesmo na região em uma determinada estação. Essa variação de resultados pode ser explicada devido às diferentes estações do ano, o que acarreta temperaturas médias distintas, variações na temperatura da água, incidência de chuvas na região e balanço do mar, tal como a presença das embarcações que estão presentes naquele litoral em determinadas épocas do ano.

\section{Conclusão}

A possibilidade de encontrar maiores níveis de lipídeos que poderão ser utilizados para a produção de biodiesel a partir de Sargassum filipendula é maior na primavera.

\section{Referências}

AZEREDO, V. B. S. "Produção de biodiesel a partir do cultivo de microalgas: estimativa de custos e perspectivas para o Brasil.”. 171. Dissertação. Universidade Federal do Rio de Janeiro. 
Rio de Janeiro. Março de 2012. Programa de Pós-Graduação em Planejamento Energético, COPPE, 2012.

BJARNSHOLT, T. The role of bacterial biofilms in chronic infections. APMIS Suppl. 2013 May;(136):1-51.

BOROWITZKA, M. A. "Commercial production of microalgae: ponds, tanks, tubes and fermenters.".Journal of Biotechnology, v. 70(1-3), p. 313-321, 1999.

DEMIRBAS, A. "Progress and recent trends in biodiesel fuels.".Energy Conversion and Management, v. 50 (1), p. 14-34, 2009. 